DOI:

UDC 662.74:669.162.16

V.D. Barsky, Doctor of Engineering Sciences, full professor

A.V. Kravchenko, Doctor of Engineering Sciences, senior researcher

Ukrainian State University of Chemical Technology, Dnipro

V.M. Gulyaev, Doctor of Engineering Sciences, full professor

D.V. Jakovlev-Barsky, post-graduate student

Dniprovsk State Technical University, Kamianske

\title{
THE CRITERIA OF CHEMICAL SIMILARITY REVISITED
}

This paper presents new criteria, taking into account the fact that "chemical" similarity should be based on the nature of change in the amount of substance and heat over time and space depending on the conditions of the process, including the temperature, pressure and composition of the reaction mixture.

Keywords: model; similarity; criterion; reaction rate.

$B$ иій роботі отримані нові критерії з урахуванням того, що «хімічна» подібність повинна спиратися на характер змінення в часі $і$ в просторі кількості речовини $і$ теплоти в залежності від умов проведення процесу, щь включать температуру, тиск і склад реакиійної сумімі.

Ключові слова: модель; подібність; критерій; швидкість реакиії.

To assess the possibility of transferring the results from the model onto a real chemicaltechnological object, it is necessary to establish the similarity of the TCP running in them not only by geometric and hydrodynamic parameters, characteristics of mass and heat transfer phenomena, but also by characteristics of chemical transformations.

Analyzing the equations that are supposed to be structurally similar for similar processes according to the definition of similarity, they reduce mathematical modeling to constructing generalized variables (similarity criteria) that have equal numerical values at similar points of the object and its model.

This allows to enter into the model not the original values but their sets, "where the structure reflects the correlation of various values" [1,c.27].

Damkehler [2] derived the criteria of "chemical" similarity from the differential equations of mass and heat transfer, considering the speed and thermal effect of the reaction as internal sources of matter and heat*.

At the same time, obviously, the "chemical" similarity should be based on the nature of the change in time and space of the amount of matter and heat, depending on the conditions of the process, including temperature, pressure and composition of the reaction mixture. the form:

In this regard, when deriving the criteria for "chemical" similarity, we use a kinetic equation of

$$
r_{\mathrm{j}}=k_{1} \Delta C_{1}-k_{2} \Delta C_{2},
$$

where $k_{1}$ and $k_{2}$ and are the rate constants, and $\Delta C_{1}$ и $\Delta C_{2}$ and are the driving forces of the direct and counter reactions (the driving forces are determined by the law of effective masses by the products of the power functions of the concentrations of the interacting substances).

This allows to present the mass transfer equation of $j$-component as follows:

$$
\frac{\partial C_{\mathrm{j}}^{\mathrm{m}}}{\partial \tau} d V+\left(\omega_{x} \frac{\partial C_{j}^{m}}{\partial x}+\omega_{y} \frac{\partial C_{j}^{m}}{\partial y}+\omega_{z} \frac{\partial C_{j}^{m}}{\partial z}\right) d V=-C_{j}^{m} \cdot\left(\frac{\partial \omega_{x}}{\partial x}+\frac{\partial \omega_{y}}{\partial y}+\frac{\partial \omega_{z}}{\partial z}\right) d V+
$$

\footnotetext{
* Examples of practical application of Damkehler criteria can be found in [3-13].
} 


$$
+D\left(\frac{\partial^{2} C_{j}^{m}}{\partial x^{2}}+\frac{\partial^{2} C_{j}^{m}}{\partial y^{2}}+\frac{\partial^{2} C_{j}^{m}}{\partial z^{2}}\right) d V+\left(k_{1} \cdot \Delta C_{1}-k_{2} \cdot \Delta C_{2}\right) d V .
$$

In equation (2), in order to simplify the similarity transformation we replace $C_{j}^{m}$ by $\rho_{\mathrm{j}}$, which is quite legitimate, because: $m=\rho \cdot V$ and

$$
C_{j}^{m}=\frac{m_{j}}{V}=\frac{\rho_{j} \cdot V}{V}=\rho_{j} .
$$

Since the volume can vary with temperature, pressure and as a result of chemical transformations, in the general case the density $\rho_{j}$ and the concentration of $j$-component of the flow should be considered as variables.

In addition, the expression in parenthesis on the left side of equation (2) (the description of convective mass transfer) and the first term of the right side of this equality (description of the discrepancy (divergence) in components of the flow velocity vector) are obtained by differentiating the products of two variables $C_{j}^{m}$ by $\omega$ :

$$
\frac{\partial\left(C_{\mathrm{j}}^{\mathrm{m}} \cdot \omega_{x}\right)}{d x}=C_{j}^{m} \frac{\partial \omega_{x}}{\partial x}+\omega_{x} \frac{d C_{j}^{m}}{d x} .
$$

Similar expressions can be written for the projections $\omega y$ and $\omega z$. This allows to present equation (2) as follows, after replacing $C_{j}^{m}$ by $\rho$ j and dividing by $d V$ :

$$
\frac{\partial \rho}{\partial \tau}+\left[\frac{\partial\left(\rho \cdot \omega_{x}\right)}{\partial x}+\frac{\partial\left(\rho \cdot \omega_{y}\right)}{\partial y}+\frac{\partial\left(\rho \cdot \omega_{z}\right)}{\partial z}\right]=D\left(\frac{\partial^{2} \rho}{\partial x^{2}}+\frac{\partial^{2} \rho}{\partial y^{2}}+\frac{\partial^{2} \rho}{\partial z^{2}}\right)+k_{1} \cdot \Delta C_{1}-k_{2} \cdot \Delta C_{2} .
$$

Now, assuming that the processes of mass transfer in the model and in the object are similar, we describe them via these equations:

$$
\begin{aligned}
& \frac{\partial \rho_{\mathrm{j}}^{\prime}}{\partial \tau^{\prime}}+\left[\frac{\partial\left(\rho_{j}^{\prime} \cdot \omega_{x}^{\prime}\right)}{\partial x^{\prime}}+\frac{\partial\left(\rho_{j}^{\prime} \cdot \omega_{y}^{\prime}\right)}{\partial y^{\prime}}+\frac{\partial\left(\rho_{j}^{\prime} \cdot \omega_{z}^{\prime}\right)}{\partial z^{\prime}}\right]=D^{\prime}\left(\frac{\partial^{2} \rho_{j}^{\prime}}{\partial\left(x^{\prime}\right)^{2}}+\frac{\partial^{2} \rho_{j}^{\prime}}{\partial\left(y^{\prime}\right)^{2}}+\frac{\partial^{2} \rho_{j}^{\prime}}{\partial\left(z^{\prime}\right)^{2}}\right)+k_{1}^{\prime} \cdot \Delta C_{1}^{\prime}-k_{2}^{\prime} \cdot \Delta C_{2}^{\prime} ; \\
& \frac{\partial \rho_{\mathrm{j}}^{\prime \prime}}{\partial \tau^{\prime \prime}}+\left[\frac{\partial\left(\rho_{j}^{\prime \prime} \cdot \omega_{x}^{\prime \prime}\right)}{\partial x^{\prime \prime}}+\frac{\partial\left(\rho_{j}^{\prime \prime} \cdot \omega_{y}^{\prime \prime}\right)}{\partial y^{\prime \prime}}+\frac{\partial\left(\rho_{j}^{\prime \prime} \cdot \omega_{z}^{\prime \prime}\right)}{\partial z^{\prime \prime}}\right]=D^{\prime \prime}\left(\frac{\partial^{2} \rho_{j}^{\prime \prime}}{\partial\left(x^{\prime \prime}\right)^{2}}+\frac{\partial^{2} \rho_{j}^{\prime \prime}}{\partial\left(y^{\prime \prime}\right)^{2}}+\frac{\partial^{2} \rho_{j}^{\prime \prime}}{\partial\left(z^{\prime \prime}\right)^{2}}\right)+k_{1}^{\prime \prime} \cdot \Delta C_{1}^{\prime \prime}-k_{2}^{\prime \prime} \cdot \Delta C_{2}^{\prime \prime} .
\end{aligned}
$$

Expressions of flow characteristics in the object through flow characteristics in the model:

$$
\begin{aligned}
& \rho_{\mathrm{j}}^{\prime \prime}=\Theta_{\rho} \cdot \rho_{j}^{\prime} ; \quad \tau^{\prime \prime}=\Theta_{\tau} \cdot \tau^{\prime} ; \quad x^{\prime \prime}=\Theta_{\mathrm{L}} \cdot x^{\prime} ; \quad y^{\prime \prime}=\Theta_{L} \cdot y^{\prime} ; \quad z^{\prime \prime}=\Theta_{L} \cdot z^{\prime} ; \\
& \omega_{x}^{\prime \prime}=\Theta_{\omega} \cdot \omega_{x}^{\prime} ; \quad \omega_{y}^{\prime \prime}=\Theta_{\omega} \cdot \omega_{y}^{\prime} ; \quad \omega_{z}^{\prime \prime}=\Theta_{\omega} \cdot \omega_{z}^{\prime} ; \\
& \mathrm{D}^{\prime \prime}=\Theta_{D} \cdot D^{\prime} ; \quad k_{1}^{\prime \prime}=\Theta_{k_{1}} \cdot k_{1}^{\prime} ; \quad \Delta C_{1}^{\prime \prime}=\Theta_{\Delta C_{1}} \cdot \Delta C_{1}^{\prime} ; \\
& k_{2}^{\prime \prime}=\Theta_{k_{2}} \cdot k_{2}^{\prime} ; \Delta C_{2}^{\prime \prime}=\Theta_{\Delta C_{2}} \cdot \Delta C_{2}^{\prime} .
\end{aligned}
$$

We now enter these expressions into equation (5):

$$
\begin{aligned}
& \frac{\Theta_{\rho}}{\Theta_{\tau}} \cdot \frac{\partial \rho_{j}^{\prime}}{\partial \tau^{\prime}}+\frac{\Theta_{\rho_{j}} \cdot \Theta_{\omega}}{\Theta_{L}} \cdot\left[\frac{\partial\left(\rho_{j}^{\prime} \cdot \omega_{x}^{\prime}\right)}{\partial x^{\prime}}+\frac{\partial\left(\rho_{j}^{\prime} \cdot \omega_{y}^{\prime}\right)}{\partial y^{\prime}}+\frac{\partial\left(\rho_{j}^{\prime} \cdot \omega_{z}^{\prime}\right)}{\partial z^{\prime}}\right]= \\
= & \frac{\Theta_{D} \cdot \Theta_{\rho}}{\Theta_{L}^{2}} \cdot D^{\prime} \cdot\left[\frac{\partial^{2} \rho_{j}^{\prime}}{\partial\left(x^{\prime}\right)^{2}}+\frac{\partial^{2} \rho_{j}^{\prime}}{\partial\left(y^{\prime}\right)^{2}}+\frac{\partial^{2} \rho_{j}^{\prime}}{\partial\left(z^{\prime}\right)^{2}}\right]+\Theta_{\mathrm{k}_{1}} \cdot \Theta_{\Delta C_{1}} \cdot k_{1}^{\prime} \cdot \Delta C_{1}^{\prime}-\Theta_{\mathrm{k}_{2}} \cdot \Theta_{\Delta C_{2}} \cdot k_{2}^{\prime} \cdot \Delta C_{2}^{\prime} .
\end{aligned}
$$

In order for equations (4) and (5) to be identical (the mass transfer processes in the model and in the object are similar), the relations between similarity constants must be equal. We are writing this equation, numbering its members: 


$$
\begin{gathered}
\left(\frac{\Theta_{\rho}}{\Theta_{\tau}}\right)=\left(\frac{\Theta_{\rho} \cdot \Theta_{\omega}}{\Theta_{L}}\right)=\left(\frac{\Theta_{D} \cdot \Theta_{\rho}}{\Theta_{L}^{2}}\right)=\left(\Theta_{k_{1}} \cdot \Theta_{\Delta C_{1}}\right)=\left(\Theta_{k_{2}} \cdot \Theta_{\Delta C_{2}}\right) \\
\text { I }
\end{gathered}
$$

We divide the elements of equation (7) one after another and we obtain the following correlation of similarity constants:

$$
\begin{aligned}
& \text { divided by I: } 1=\frac{\Theta_{\omega} \cdot \Theta_{\tau}}{\Theta_{\mathrm{L}}}=\frac{\Theta_{D} \cdot \Theta_{\tau}}{\Theta_{L}^{2}}=\frac{\Theta_{k_{1}} \cdot \Theta_{\Delta C_{1}} \cdot \Theta_{\tau}}{\Theta_{\rho}}=\frac{\Theta_{k_{2}} \cdot \Theta_{\Delta C_{2}} \cdot \Theta_{\tau}}{\Theta_{\rho}} ; \\
& \text { divided by II: } \frac{\Theta_{L}}{\Theta_{\tau} \cdot \Theta_{\omega}}=1=\frac{\Theta_{D}}{\Theta_{L} \cdot \Theta_{\omega}}=\frac{\Theta_{k_{1}} \cdot \Theta_{\Delta C_{1}} \cdot \Theta_{L}}{\Theta_{\rho} \cdot \Theta_{\omega}}=\frac{\Theta_{k_{2}} \cdot \Theta_{\Delta C_{2}} \cdot \Theta_{L}}{\Theta_{\rho} \cdot \Theta_{\omega}} ;
\end{aligned}
$$$$
\text { divided by III: } \frac{\Theta_{L}^{2}}{\Theta_{\tau} \cdot \Theta_{D}}=\frac{\Theta_{\omega} \cdot \Theta_{L}}{\Theta_{D}}=1=\frac{\Theta_{k_{1}} \Theta_{\Delta C_{1}} \cdot \Theta_{L}^{2}}{\Theta_{D} \cdot \Theta_{\rho}}=\frac{\Theta_{k_{2}} \cdot \Theta_{\Delta C_{2}} \cdot \Theta_{L}^{2}}{\Theta_{D} \cdot \Theta_{\rho}} \text {; }
$$$$
\text { divided by IV: } \frac{\Theta_{\rho}}{\Theta_{\tau} \cdot \Theta_{k_{1}} \cdot \Theta_{\Delta C_{1}}}=\frac{\Theta_{\omega} \cdot \Theta_{\rho}}{\Theta_{L} \cdot \Theta_{k_{1}} \cdot \Theta_{\Delta C_{1}}}=\frac{\Theta_{D} \cdot \Theta_{\rho}}{\Theta_{L}^{2} \cdot \Theta_{k_{1}} \cdot \Theta_{\Delta C_{1}}}=1=\frac{\Theta_{k_{2}} \cdot \Theta_{\Delta C_{2}}}{\Theta_{k_{1}} \cdot \Theta_{\Delta C_{2}}} \text {; }
$$

divided by V: $\frac{\Theta_{\rho}}{\Theta_{k_{2}} \cdot \Theta_{\Delta C_{2}} \cdot \Theta_{\tau}}=\frac{\Theta_{\rho} \cdot \Theta_{\omega}}{\Theta_{k_{2}} \cdot \Theta_{\Delta C_{2}} \cdot \Theta_{L}}=\frac{\Theta_{D} \cdot \Theta_{\rho}}{\Theta_{k_{2}} \cdot \Theta_{\Delta C_{2}} \cdot \Theta_{L}^{2}}=\frac{\Theta_{k_{1}} \cdot \Theta_{\Delta C_{1}}}{\Theta_{k_{2}} \cdot \Theta_{\Delta C_{2}}}=1$.

Typically, since the relations of similarity constants, located on opposite sides of the diagonal consisting of figures, mirror each other, we consider only ten of the twenty complexes, from which we exclude the interdependent, i.e. those that can be obtained by multiplying and dividing independent criteria.

We are determined to view well-known criteria of homochronicity (I.2), the diffusion Fourier criterion (I.3), the inverse diffusion Péclet criterion (II.3) as independent. Now

- we multiply II.4 by I.2 and we get I.4:

$$
\frac{k_{1} \cdot \Delta \mathrm{C}_{1} \cdot L}{\rho \cdot \omega} \cdot \frac{\omega \cdot \tau}{L}=\frac{k_{1} \cdot \Delta C_{1} \cdot \tau}{\rho}
$$

- we multiply II.5 by I.2 and receive I.5:

$$
\frac{k_{2} \cdot \Delta \mathrm{C}_{2} \cdot L}{\rho \cdot \omega} \cdot \frac{\omega \cdot \tau}{L}=\frac{k_{2} \cdot \Delta C_{2} \cdot \tau}{\rho}
$$

- now we multiply II.4 by III.2 (Pe $\left.\mathrm{P}_{\mathrm{D}}\right)$ and obtain III.4:

$$
\frac{k_{1} \cdot \Delta \mathrm{C}_{1} \cdot L}{\rho \cdot \omega} \cdot \frac{\omega \cdot \tau}{D}=\frac{k_{1} \cdot \Delta C_{1} \cdot L^{2}}{D \cdot \rho}
$$

- we multiply II.5 by III.2 $\left(\mathrm{Pe}_{\mathrm{D}}\right)$ and obtain III.5:

$$
\frac{k_{2} \cdot \Delta \mathrm{C}_{2} \cdot L}{\rho \cdot \omega} \cdot \frac{\omega \cdot \tau}{D}=\frac{k_{2} \cdot \Delta C_{2} \cdot L^{2}}{D \cdot \rho} \text {. }
$$

From the results obtained, it follows that of the seven criteria, including the kinetic characteristics of the reaction, four are dependent. Moreover, by multiplying II.4 by IV.5, we obtain:

$$
\frac{k_{1} \cdot \Delta \mathrm{C}_{1} \cdot L}{\rho \cdot \omega} \cdot \frac{k_{2} \cdot \Delta C_{2}}{k_{1} \cdot \Delta C_{1}}=\frac{k_{2} \cdot \Delta C_{2} \cdot L}{\rho \cdot \omega}
$$

thus, criterion II.5 turns to be dependent as well.

Let us call independent criterion II.4 "the chemical criterion" (CC), and criterion IV.5 "the chemical non-equilibrium" (CNE).

Hence, the similarity of mass transfer processes requires that at similar points of a model and an object the following criteria have the same values: 
- homochronicity

- Fourier diffusion criterion

- Péclet diffusion criterion

- chemical kinetic

- chemical non-equilibrium

$$
\begin{aligned}
& \frac{\omega \cdot \tau}{L}=\mathrm{Ho} ; \\
& \frac{D \cdot \tau}{L^{2}}=\mathrm{Fo}_{D} ; \\
& \frac{\omega \cdot L}{D}=\mathrm{Pe}_{D} ; \\
& \frac{k_{1} \cdot \Delta C_{1} \cdot L}{\omega \cdot \rho}=C K ; \\
& \frac{k_{2} \cdot \Delta C_{2}}{k_{1} \cdot \Delta C_{1}}=C N E .
\end{aligned}
$$

When modeling CTP with model-to-object similarity, it is typically necessary to take into account the thermal effects of the direct and counter reactions. In this case, we consider as similar the thermal processes described by the same differential equation.

In this regard, the similarity criteria of two thermal processes are derived from the FourierKirchhoff equation in the same way as the hydrodynamic similarity criteria are derived from the equations of continuity of the medium and motion of Navier-Stockes.

The equation of heat transfer, after dividing all its members by $\rho C_{p} d V$, is represented as follows:

$$
\frac{\partial T}{\partial \tau}+\left(\omega_{x} \frac{\partial T}{\partial x}+\omega_{y} \frac{\partial T}{\partial y}+\omega_{z} \frac{\partial T}{\partial z}\right)=a\left(\frac{\partial^{2} T}{\partial x^{2}}+\frac{\partial^{2} T}{\partial y^{2}}+\frac{\partial^{2} T}{\partial z^{2}}\right)+\frac{q_{1}}{\rho \cdot C_{p}} \cdot k_{1} \Delta C_{1}-\frac{q_{2}}{\rho \cdot C_{p}} \cdot k_{2} \Delta C_{2},
$$

where $q_{1}$ and $q_{2}$ - are the specific thermal effects of direct and counter chemical reactions, $J / \mathrm{kg}$.

It can be observed that all members of the equation (8) have the same units of measurement and reflect the rate of temperature change due to heat transfer in the flow of the reaction mixture, the where the interaction of components is accompanied by thermal effect.

For flows satisfying the thermal similarity condition, the equations of the form (8) can be represented as follows:

$$
\begin{aligned}
& \frac{\partial T^{\prime}}{\partial \tau^{\prime}}+\left(\omega_{x}^{\prime} \frac{\partial T^{\prime}}{\partial x^{\prime}}+\omega_{y}^{\prime} \frac{\partial T^{\prime}}{\partial y^{\prime}}+\omega_{z}^{\prime} \frac{\partial T^{\prime}}{\partial z^{\prime}}\right)= \\
& =a^{\prime}\left(\frac{\partial^{2} T^{\prime}}{\partial\left(x^{\prime}\right)^{2}}+\frac{\partial^{2} T^{\prime}}{\partial\left(y^{\prime}\right)^{2}}+\frac{\partial^{2} T^{\prime}}{\partial\left(z^{\prime}\right)^{2}}\right)+\frac{q_{1}^{\prime}}{\rho^{\prime} \cdot C_{p}^{\prime}} \cdot k_{1}^{\prime} \Delta C_{1}^{\prime}-\frac{q_{2}^{\prime}}{\rho^{\prime} \cdot C_{p}^{\prime}} \cdot k_{2}^{\prime} \Delta C_{2}^{\prime} ; \\
& \frac{\partial T^{\prime \prime}}{\partial \tau^{\prime \prime}}+\left(\omega_{x}^{\prime \prime} \frac{\partial T^{\prime \prime}}{\partial x^{\prime \prime}}+\omega_{y}^{\prime \prime} \frac{\partial T^{\prime \prime}}{\partial y^{\prime \prime}}+\omega_{z}^{\prime} \frac{\partial T^{\prime \prime}}{\partial z^{\prime \prime}}\right)= \\
& =a^{\prime \prime}\left(\frac{\partial^{2} T^{\prime \prime}}{\partial\left(x^{\prime \prime}\right)^{2}}+\frac{\partial^{2} T^{\prime \prime}}{\partial\left(y^{\prime \prime}\right)^{2}}+\frac{\partial^{2} T^{\prime \prime}}{\partial\left(z^{\prime \prime}\right)^{2}}\right)+\frac{q_{1}^{\prime \prime}}{\rho^{\prime \prime} \cdot C_{p}^{\prime \prime}} \cdot k_{1}^{\prime \prime} \Delta C_{1}^{\prime \prime}-\frac{q_{2}^{\prime \prime}}{\rho^{\prime \prime} \cdot C_{p}^{\prime \prime}} \cdot k_{2}^{\prime \prime} \Delta C_{2}^{\prime \prime} .
\end{aligned}
$$

Having defined similarity constants with the expressions:

$$
\begin{aligned}
& \frac{\tau^{\prime \prime}}{\tau^{\prime}}=\Theta_{\tau} ; \quad \frac{T^{\prime \prime}}{T^{\prime}}=\Theta_{T} ; \quad \frac{x^{\prime \prime}}{x^{\prime}}=\frac{y^{\prime \prime}}{y^{\prime}}=\frac{z^{\prime \prime}}{z^{\prime}}=\Theta_{l} ; \\
& \frac{\omega_{x}^{\prime \prime}}{\omega_{x}^{\prime}}=\frac{\omega_{y}^{\prime \prime}}{\omega_{y}^{\prime}}=\frac{\omega_{z}^{\prime \prime}}{\omega_{z}^{\prime}}=\Theta_{\omega} ; \quad \frac{a^{\prime \prime}}{a^{\prime}}=\Theta_{a} ; \quad \frac{q_{1}^{\prime \prime}}{q_{1}^{\prime}}=\Theta_{q_{1}} ; \quad \frac{q_{2}^{\prime \prime}}{q_{2}^{\prime}}=\Theta_{q_{2}} ;
\end{aligned}
$$




$$
\frac{\rho^{\prime \prime}}{\rho^{\prime}}=\Theta_{\rho} ; \quad \frac{C_{p}^{\prime \prime}}{C_{p}^{\prime \prime}}=\Theta_{C_{p}} ; \frac{r_{2}^{\prime \prime}}{r_{1}^{\prime \prime}}=\Theta_{r_{1}} ; \quad \frac{r_{2}^{\prime \prime}}{r_{1}^{\prime \prime}}=\Theta_{r_{2}},
$$

and substituting them in (10), we find that in order for equations (9) and (10) to completely match it is required that all the coefficients of equation (10) formed by the similarity constants, are equal to each other:

$$
\frac{\Theta_{T}}{\Theta_{\tau}}=\frac{\Theta_{\omega} \cdot \Theta_{T}}{\Theta_{L}}=\frac{\Theta_{a} \cdot \Theta_{T}}{\Theta_{L}^{2}}=\frac{\Theta_{q_{1}} \cdot \Theta_{r_{1}}}{\Theta_{\rho} \cdot \Theta_{C_{P}}}=\frac{\Theta_{\mathrm{q}_{2}} \cdot \Theta_{r_{2}}}{\Theta_{\rho} \cdot \Theta_{C p}}
$$

$$
\text { I II III IV V }
$$

(in order to simplify the presentation here and above we take $r_{1}$ instead of $k_{1} \Delta C_{1}$ and instead of $k_{2} \Delta C_{2}$ we took $r_{2}$ ).

Just like in the case of similarity in mass transfer processes, by dividing each of the elements of equation (11) by any of them, we obtain the following relations:

When dividing

by I: $\quad 1=\frac{\Theta_{\omega} \cdot \Theta_{\tau}}{\Theta_{L}}=\frac{\Theta_{a} \cdot \Theta_{\tau}}{\Theta_{L}^{2}}=\frac{\Theta_{q_{1}} \cdot \Theta_{r_{1}} \cdot \Theta_{\tau}}{\Theta_{\rho} \cdot \Theta_{C_{p}} \cdot \Theta_{T}}=\frac{\Theta_{q_{2}} \cdot \Theta_{r_{2}} \cdot \Theta_{\tau}}{\Theta_{\rho} \cdot \Theta_{C_{p}} \cdot \Theta_{T}}$;

by II: $\frac{\Theta_{L}}{\Theta_{\omega} \cdot \Theta_{\tau}}=1=\frac{\Theta_{a}}{\Theta_{\omega} \cdot \Theta_{L}}=\frac{\Theta_{q_{1}} \cdot \Theta_{r_{1}} \cdot \Theta_{L}}{\Theta_{\rho} \cdot \Theta_{C_{p}} \cdot \Theta_{\omega} \cdot \Theta_{T}}=\frac{\Theta_{q_{2}} \cdot \Theta_{r_{2}} \cdot \Theta_{L}}{\Theta_{\rho} \cdot \Theta_{C_{p}} \cdot \Theta_{\omega} \cdot \Theta_{T}}$;

by III: $\frac{\Theta_{L}^{2}}{\Theta_{a} \cdot \Theta_{\tau}}=\frac{\Theta_{\omega} \cdot \Theta_{L}}{\Theta_{a}}=1=\frac{\Theta_{q_{1}} \cdot \Theta_{r_{1}} \cdot \Theta_{L}^{2}}{\Theta_{\rho} \cdot \Theta_{C_{p}} \cdot \Theta_{a} \cdot \Theta_{T}}=\frac{\Theta_{q_{2}} \cdot \Theta_{r_{2}} \cdot \Theta_{L}^{2}}{\Theta_{\rho} \cdot \Theta_{C_{p}} \cdot \Theta_{a} \cdot \Theta_{T}}$

by IV: $\frac{\Theta_{\rho} \cdot \Theta_{C_{p}} \cdot \Theta_{T}}{\Theta_{q_{1}} \cdot \Theta_{r_{1}} \cdot \Theta_{\tau}}=\frac{\Theta_{\rho} \cdot \Theta_{C_{p}} \cdot \Theta_{\omega} \cdot \Theta_{T}}{\Theta_{q_{1}} \cdot \Theta_{r_{1}} \cdot \Theta_{\mathrm{L}}}=\frac{\Theta_{\rho} \cdot \Theta_{C_{p}} \cdot \Theta_{a} \cdot \Theta_{T}}{\Theta_{q_{1}} \cdot \Theta_{r_{1}} \cdot \Theta_{L}^{2}}=1=\frac{\Theta_{\mathrm{q}_{2}} \cdot \Theta_{r_{2}}}{\Theta_{q_{1}} \cdot \Theta_{r_{1}}}$;

by V: $\frac{\Theta_{\rho} \cdot \Theta_{C_{p}} \cdot \Theta_{T}}{\Theta_{q_{2}} \cdot \Theta_{r_{2}} \cdot \Theta_{\tau}}=\frac{\Theta_{\rho} \cdot \Theta_{C_{p}} \cdot \Theta_{\omega} \cdot \Theta_{T}}{\Theta_{q_{2}} \cdot \Theta_{r_{2}} \cdot \Theta_{L}}=\frac{\Theta_{\rho} \cdot \Theta_{C_{p}} \cdot \Theta_{a} \cdot \Theta_{T}}{\Theta_{q_{2}} \cdot \Theta_{r_{2}} \cdot \Theta_{L}^{2}}=\frac{\Theta_{\mathrm{q}_{1}} \cdot \Theta_{r_{1}}}{\Theta_{q_{2}} \cdot \Theta_{r_{2}}}=1$.

It can be seen that relations of similarity constants located above the diagonal, made up of units, are as mentioned before inverse functions of the relations located below this diagonal. Therefore, we can consider only ten of the twenty similarity criteria, having previously assigned numbers 1, 2, 3, 4 and 5 to the columns of the above mentioned matrix:

Taking the criterion of homochronicity (I.2), thermal Fourier criterion (I.3) and inverse thermal Peclet criterion (II.3) as independent criteria we find the dependent similarity criteria:

I.4, by multiplying II.4 by I.2:

$\frac{q_{1} \cdot k_{1} \cdot \Delta \mathrm{C}_{1} \cdot L}{\rho \cdot C p \cdot \omega \cdot T} \cdot \frac{\omega \cdot \tau}{L}=\frac{q_{1} \cdot k_{1} \cdot \Delta C_{1} \cdot \tau}{\rho \cdot C p \cdot T}$

I. 5 , by multiplying II. 5 by I.2:

$\frac{q_{2} \cdot k_{2} \cdot \Delta C_{2} \cdot L}{\rho \cdot C p \cdot \omega \cdot T} \cdot \frac{\omega \cdot \tau}{L}=\frac{q_{2} \cdot k_{2} \cdot \Delta C_{2} \cdot \tau}{\rho \cdot C p \cdot T} ;$

III.4, by multiplying II.4 by III.2 $\left(\mathrm{Pe}_{\mathrm{T}}\right)$ :

$\frac{q_{1} \cdot k_{1} \cdot \Delta C_{1} \cdot L}{\rho \cdot C p \cdot \omega \cdot T} \cdot \frac{\omega \cdot L}{a}=\frac{q_{1} \cdot k_{1} \cdot \Delta C_{1} \cdot L^{2}}{\rho \cdot C p \cdot T \cdot a} ;$

III.5, by multiplying II.5 by III.2 $\left(\mathrm{Pe}_{\mathrm{T}}\right)$ :

$\frac{q_{2} \cdot k_{2} \cdot \Delta C_{2} \cdot L}{\rho \cdot C p \cdot \omega \cdot T} \cdot \frac{\omega \cdot L}{a}=\frac{q_{2} \cdot k_{2} \cdot \Delta C_{2} \cdot L^{2}}{\rho \cdot C p \cdot T \cdot a} ;$

II. 5 , by multiplying II.4 by IV.5: 


$$
\frac{q_{1} \cdot k_{1} \cdot \Delta C_{1} \cdot L}{\rho \cdot C p \cdot \omega \cdot T} \cdot \frac{\mathrm{q}_{2} \cdot k_{2} \cdot \Delta \mathrm{C}_{2}}{\mathrm{q}_{1} \cdot k_{1} \cdot \Delta \mathrm{C}_{1}}=\frac{q_{2} \cdot k_{2} \cdot \Delta C_{2} \cdot L}{\rho \cdot C p \cdot \omega \cdot T} .
$$

It follows from the obtained results that in addition to the known thermal criteria for the similarity in heat transfer phenomena, in the processes with chemical transformations we should take into account independent criteria II.4 and IV.5, which we previously called, respectively, thermochemical kinetic (TCK) and chemical nonequilibrium (CNE) .

Thus, the full set of similarity criteria in CTP, occurring in the model and the object, and described by the same differential heat transfer equations, includes the following correlations of physical values - the criteria of:

$\begin{array}{ll}\text { - homochronicity } & \frac{\omega \cdot \tau}{L}=\mathrm{Ho} ; \\ \text { - heat, Fourier } & \frac{a \cdot \tau}{L^{2}}=\mathrm{Fo}_{T} ; \\ \text { - heat, Péclet } & \frac{\omega \cdot L}{\mathrm{a}}=\mathrm{Pe}_{T} ; \\ \text { - thermochemical kinetic } & \frac{q \cdot k_{1} \cdot \Delta C_{1} \cdot L}{\rho \cdot C_{p} \cdot \omega \cdot T}=T C K ; \\ \text { - chemical non-equilibrium } & \frac{k_{2} \cdot \Delta C_{2}}{k_{1} \cdot \Delta C_{1}}=C N E .\end{array}$

Extending the effect of Lavoisier-Laplace Ist law of thermochemistry (1780-1784) to our case we received the last two criteria, accepting $q_{1}=q_{2}=|q|$.

In equilibrium, when $k_{1} \Delta C_{1} \approx k_{2} \Delta C_{2}$, the criterion $C N E \rightarrow 1$.

It is observed that for an almost irreversible (with maximum permissible deviation from equilibrium) process, when $k_{1} \Delta C_{1} \gg>k_{2} \Delta C_{2}$, the value of the criterion $C N E \rightarrow 0$.

Thus, the domain of definition of the similarity criterion for chemical-technological processes according to the degree of their disequilibrium is defined by the inequation:

$0 \leq C N E \leq 1$,

similar for phenomena of both matter and heat transfer.

For the sake of completeness, let us note that it is only with $C N E=0$ (an irreversible process) that the rate of CTP is determined by the speed of direct reaction and the criterion $C K$ matches the Damkeler criterion DaI, while the criterion TCK - the criterion DaIII.

In addition, the criteria obtained by us are in tune with the criteria suggested by G.K. Diaconov $[14,15]$.

Thus, in order to confirm the transferability of the model to a real object one needs to make sure that the TCP running in them are similar not only in traditional criteria, but also in correlations of speed of direct reaction to the flow rate $(C K)$, the change rate of thermal effect of the reaction to the change rate of heat flow, as well as in the remoteness of the process from the state of chemical equilibrium.

Undoubtedly, taking into account the criteria of chemical similarity complicates the development of the material (physical) model of an object, but it does not impose any fundamental restrictions on the similarity modeling of chemical-technological processes [16].

\section{List of reference links}

[1] Guxman, A. A. Vedenie v teoriyu podobiya. - M.:Vysshaya Shkola, 1963. - $255 \mathrm{~s}$.

[2] Damkohler, G. Chem. Fabrik. - 1939. - Bd. 43, 44.

[3] Zakgejm, A. Yu. Obshhaya ximicheskaya texnologiya: vvedenie v modelirovanie ximikotexnologicheskix processov: ucheb. posobie / A. Yu. Zakgejm - Logos, 2009. - 303 s. 
[4] Yakovlev, Yu. N. Fiziko-ximicheskoe podobie metallurgicheskix processov/ Yu. N. Yakovlev, L.V. Kamkina// Sbornik nauchnyx trudov Gosudarstvennoj metallurgicheskoj akademii Ukrainy «Sovremennye problemy metallurgii». Dnepropetrovsk, 1999, Vip. 1 - S. 90-100.

[5] Kamkina, L. V. Ispolzovanie fiziko-ximicheskogo podobiya pri issledovanii i analize staleplavilnyx processov/ L.V. Kamkina, A.G. Velichko// Sbornik dokladov mezhdunarodnoj nauchno-prakticheskoj konferencii «Tvorcheskoe nasledie V.E. Grum-Grzhimajlo: proshloe, sovremennoe sostoyanie, budushhee» (27-29 marta 2014g.): sbornik dokladov. - Ekaterinburg, 2014. - Ch.1. - S. 259-265.

[6] Zuev, K. I. Osnovy teorii podobiya: konspekt lekcij / K.I. Zuev. - Vladimir: izd. Vladimirskij gosudarstvennyj universitet, 2011. - 51s.

[7] Maksimov, A. I. Modeli i modelirovanie v nauchnyx issledovaniyax: ucheb. posobie po kursu «Metodologiya nauchnyx issledovanij»/ A.I. Maksimov - Ivanovo: GOU VPO Ivan. gos. xim.texnol. un.-t., 2006. -88 s.

[8] Gumerov, A.M. Matematicheskoe modelirovanie ximiko-texnologicheskix processov. - SanktPeterburg: Lan, 2014. - 176 s.

[9] Ponomarev, V.B. Matematicheskoe modelirovanie ximiko-texnologicheskix processov: kurs lekcij/V.B. Ponomarev, A.B. Loshkarev. - Ekaterinburg: GOU VPO UGTU - UPI, 2006. - 129 s.

[10] Kravcov, A. V. Matematicheskoe modelirovanie mnogokomponentnyx ximicheskix processov: uchebnoe. posobie - 2-e izd./ A. V. Kravcov, N. V. Usheva, O. E. Mojzes, A. F. Fedorov. Tomsk: izd. Tomskij politexnicheskij universitet, 2015. - $108 \mathrm{~s}$.

[11] Pinchuk S.I. Organizaciya eksperimenta pri modelirovanii i optimizacii texnicheskix sistem. Uchebnoe posobie, Dnepropetrovsk, Izd. «Diva», 2008. - s. 248.

[12] Smirnov A.S., Fedorov K.M.,Shevelev A.P. O modelirovanii kislotnogo vozdejstviya na karbonatnyj plast // Izvestiya RAN. Seriya MZhG. - 2010. - № 5. - s. 114-121.

[13] Smirnov A.S. Matematicheskoe modelirovanie processa zakachki kisloty v karbonatnyj plast $\mathrm{s}$ uchetom formirovaniya «chervotochin»: Avtoref. dis...kand. fiz.-mat. nauk: 01.02.05 / Tyumenskij gos. un-t.- Tyumen, 2011. $-26 \mathrm{~s}$.

[14] Dyakonov, G. K. Modelirovanie processov fiziko- ximicheskix prevrashhenij. - M.: izd. AN SSSR, 1951. $-285 \mathrm{~s}$.

[15] Dyakonov, G. K. Voprosy teorii podobiya v oblasti fiziko- ximicheskix processov. - M. - L: izd. AN SSSR, 1956. - $206 \mathrm{~s}$.

[16] Barsky V.D. About limitations on similarity modelling of chemical-technological processes./ Barsky V.D., Kravchenko A.V., Gulyaev V.M., Jakovlev-Barsky D.V. - Mathematical modeling. - 2018. - №2(39). - s. 154-162.

\section{ЩЕ РАЗ ПРО КРИТЕРІЇ ХІМІЧНОЇ ПОДІБНОСТІ}

Барський В.Д., Кравченко О.В., Гуляєв В.М., Яковлєв-Барський Д.В.

\section{Реферат}

Для оцінки можливості переносу результатів 3 фізичної моделі на реальний хімікотехнологічний об'єкт встановлюють подібність ХТП, що протікають в них, враховуючи геометричні і гідродинамічні параметри, характеристики явищ масо- і тепло переносу та хімічних перетворень.

Досліджуючи рівняння, які по визначенню подібності повинні бути структурно однаковими для подібних процесів, математичне моделювання зводять до побудови узагальнених змінних (критеріїв подібності), що мають рівні чисельні значення в схожих точках об’єкта та його моделі.

Це дозволяє вводити в модель замість первісних величин їх комплекси, «в самій структурі яких відображено взаємодію різних величин». 
Відомі критерії «хімічної» подібності, виведені із диференційних рівнянь масо- і теплопереносу, в яких швидкість і тепловий ефект реакції розглядаються як внутрішні джерела речовини і теплоти.

В цій роботі отримані нові критерії з урахуванням того, що «хімічна» подібність повинна спиратися на характер змінення в часі і в просторі кількості речовини і теплоти в залежності від умов проведення процесу, що включать температуру, тиск і склад реакційної суміші.

В зв'язку з цим при виводі критеріїв «хімічної» подібності використано кінетичне рівняння, що включає константи швидкості (як температурні залежності), рушійні сили прямої і зворотної реакцій (рушійні сили за законом діючих мас визначаються добутками степеневих функцій концентрацій речовин, що взаємодіють).

В результаті показано, що об'єкт і модель є подібними, якщо в їх схожі точках опиняються рівними значення не тільки критеріїв гомохронності, дифузійних і теплових критеріїв Фур’є і Пекле, а і критерії:

- хімічного кінетичного

$$
\begin{array}{ll}
\text { - хімічного кінетичного } & \frac{k_{1} \cdot \Delta C_{1} \cdot L}{\omega \cdot \rho}=X K \\
\text { - термохімічного кінетичного } & \frac{q \cdot k_{1} \cdot \Delta C_{1} \cdot L}{\rho \cdot C_{p} \cdot \omega \cdot T}=T X K .
\end{array}
$$

Крім того, висновки, що базуються на диференційних рівняннях не тільки масопереносу, а і теплопереносу, привели до одного й того ж критерію:

$$
\text { - хімічного нерівноважного } \frac{k_{2} \cdot \Delta C_{2}}{k_{1} \cdot \Delta C_{1}}=X H P \text {. }
$$

Таким чином, для твердження про традуктивність моделі реальному об'єкту треба, щоб хіміко-технологічні процеси, що протікають в них, були подібні не тільки по традиційним критеріям, а і по співвідношенням швидкості прямої реакції до швидкості потоку (ХК), швидкості змінення теплового ефекту реакції до швидкості змінення кількості теплоти в потоці, а також по віддаленості процесу від стану хімічної рівноваги.

\section{Література}

1. Гухман А. А. Ведение в теорию подобия / А. А. Гухман - М.: Высшая школа, 1963. -255 с.

2. Damkohler, G. Chem. Fabrik. - 1939. - Bd. 43, 44.

3. Закгейм А. Ю. Общая химическая технология: введение в моделирование химикотехнологических процессов: учеб. пособие / А. Ю. Закгейм - Логос, 2009. - 303 с.

4. Яковлев Ю. Н. Физико-химическое подобие металлургических процессов / Ю. Н. Яковлев, Л.В. Камкина// Сборник научных трудов Государственной металлургической академии Украины «Современные проблемы металлургии». Днепропетровск, 1999, Вип. 1 - С. 90-100.

5. Камкина Л. В. Использование физико-химического подобия при исследовании и анализе сталеплавильных процессов/ Л.В. Камкина, А.Г. Величко // Сборник докладов международной научно-практической конференции «Творческое наследие В.Е. ГрумГржимайло: прошлое, современное состояние, будущее» (27-29 марта 2014г.): сборник докладов. - Екатеринбург, 2014. - Ч.1. - С. 259-265.

6. Зуев К. И. Основы теории подобия: конспект лекций / К.И. Зуев. - Владимир: изд. Владимирский государственный университет, 2011. - 51 с.

7. Максимов А. И. Модели и моделирование в научных исследованиях: учеб. пособие по курсу «Методология научных исследований» / А.И. Максимов - Иваново: ГОУ ВПО Иван. гос. хим.-технол. ун.-т., 2006. -88 с.

8. Гумеров А. М. Математическое моделирование химико-технологических процессов / А. М. Гумеров - Санкт-Петербург: Лань, 2014. - 176 с.

9. Пономарев В.Б. Математическое моделирование химико-технологических процессов: курс лекций / В.Б. Пономарев, А.Б. Лошкарев. - Екатеринбург: ГОУ ВПО УГТУ - УПИ, 2006. $129 \mathrm{c.}$ 
10. Кравцов А. В. Математическое моделирование многокомпонентных химических процессов: учебное. пособие - 2-е изд. / А. В. Кравцов, Н. В. Ушева, О. Е. Мойзес, А. Ф. Федоров. Томск: изд. Томский политехнический университет, 2015. - 108 с.

11.Пинчук С. И. Организация эксперимента при моделировании и оптимизации технических систем / С.И. Пинчук - Учебное пособие, Днепропетровск, Изд. «Дива», 2008. - 248 с.

12.Смирнов А.С., Федоров К.М.,Шевелев А.П. О моделировании кислотного воздействия на карбонатный пласт // Известия РАН. Серия МЖГ. - 2010. -№ 5. - с. 114-121.

13.Смирнов А.С. Математическое моделирование процесса закачки кислоты в карбонатный пласт с учетом формирования «червоточин»: Автореф. дис...канд. физ.-мат. наук: 01.02 .05 / Тюменский гос. ун-т. - Тюмень, 2011. - 26 с.

14.Дьяконов Г. К. Моделирование процессов физико- химических превращений / Г. К.Дьяконов - М.: изд. АН СССР, 1951. -285 с.

15.Дьяконов Г. К. Вопросы теории подобия в области физико- химических процессов / Г. К. Дьяконов- М. - Л: изд. АН СССР, 1956. - 206 с.

16. Barsky V.D. About limitations on similarity modelling of chemical-technological processes./ Barsky V.D., Kravchenko A.V., Gulyaev V.M., Jakovlev-Barsky D.V. - Mathematical modeling. 2018. - № 2(39). - s. 154-162. 